\title{
Anochece en Santa Ana: microhistoria de un barangay filipino y su conexión con el mundo globalizado de la segunda mitad del siglo XVII*
}

\author{
Dusk in Santa Ana: Microhistory of a Philippine Barangay \\ and its Conexion with the Globalized World \\ of the Second Half of $17^{\text {th }}$ Century
}

\author{
José Miguel Herrera Reviriego \\ ORCID iD: https://orcid.org/0000-0002-9789-8157 \\ Universitat Jaume I, Castelló de la Plana, España
}

La noche del 12 de marzo de 1670, un grupo de marineros que se dirigían al galeón de Manila San Diego asaltaron el barangay o poblado filipino de Santa Ana en busca de comida. Este hecho, aunque aislado y a simple vista sin gran transcendencia, nos permite vislumbrar ciertos aspectos de la vida del medio agrícola filipino. A partir de este caso, se aprecia cómo este pequeño poblado no era una pieza aislada del resto de globo, sino que se encontraba interconectado con diversas redes comerciales y culturales, siendo participe de la conocida como "primera globalización».

Palabras Clave: Filipinas; Tondo; Microhistoria; Historia conectada; primera globalización; Galeón de Manila.

On the night of March 12, 1670, a group of sailors on their way to the Manila's Galleon San Diego raided the Filipino barangay or village of Santa Ana in search of food. This fact, although isolated, allows us to view certain aspects of the life of the Philippine agricultural environment. From this case, we can appreciate how this nucleus was not an isolated piece from the rest of the globe, but was interconnected with various commercial and cultural networks, thus taking part in the so-called «first globalization».

KeYwords: Philippinnes; Tondo; Microhistory; Connected History; First Globalization; Manila Galleon.

Copyright: (C) 2021 CSIC. Este es un artículo de acceso abierto distribuido bajo los términos de la licencia de uso y distribución Creative Commons Reconocimiento 4.0 Internacional (CC BY 4.0).

* Este trabajo se enmarca en el proyecto «El sudeste asiático bajo la influencia ibérica en el mundo, 1581-1668» (PID2019-107430GB-I00), aprobado y financiado por el Ministerio de Ciencia e Innovación y la Agencia Nacional de Investigación, España. 
Anochece en Santa Ana, y el pequeño pueblo filipino se prepara para sumergirse en el letargo de la noche. En orilla del río, el cabeza del barangay ${ }^{1}$ Antonio de Espíritu ordena los utensilios de pesca de su canoa. El viento de marzo ha dado una tregua y las aguas están más calmadas que de costumbre, parece que, si la suerte le acompaña, tendrá una buena noche de capturas. Unos metros tierra adentro se encuentra su hermano, José de la Cruz, quien, tras un duro día de travesía, acaba de llegar de Manila de depositar los tributos pagados por el poblado en los Reales Almacenes de la ciudad. Mientras tanto, la mestiza de sangley Florentina de la Cruz prepara la cena, y el aire se inunda con el olor de exóticas especias asiáticas, pues esta noche aderezará el arroz recogido en su sementera con una salsa de rábanos y mostaza. Solamente una suave melodía rompe la quietud de estas horas, se trata del pampango Diego Catacotar, quien, tras un duro día de trabajo en el campo de maíz de su amigo Domingo de Ramos, ha decidido amenizar las últimas horas del día con los acordes de su guitarra.

A unos pocos metros del poblado, un pequeño navío que se dirigía hacia Lampón para suministrar materiales para la construcción del Galeón de Manila San Diego, ha echado anclas ante la incapacidad de seguir navegando por el río. La falta de viento y la quietud de las aguas, que facilitan a Antonio de Espíritu su jornada de pesca, no han sido tan beneficiosas para la travesía del navío. Con la noche cerrándose cada vez más, y al amparo de la oscuridad de la luna nueva, sus marineros decidieron bajar a tierra. Gracias a ellos, la quietud vivida durante el anochecer en Santa Ana se iba a quebrar súbitamente con la caída del crepúsculo.

\section{Santa Ana: entre la microhistoria y la globalización}

Los sucesos acontecidos durante la madrugada del 12 de marzo de 1670 en el pequeño poblado de Santa $\mathrm{Ana}^{2}$ pueden parecer insignificantes

1 Los cabezas de barangay eran miembros de la principalía indígena filipina, contaban con ciertos privilegios sobre el resto de población y eran los encargados de recaudar los tributos en su barangay o pueblo. Entre ellos, destacaban los gobernadorcillos, quienes poseían ciertas funciones administrativas de carácter municipal. Alonso Álvarez, 2005.

2 El barangay de Santa Ana se situaba en las inmediaciones de la ciudad de Manila, pero, jurisdiccionalmente, pertenecía a Tondo, provincia que englobaba a gran parte de las lowlands que circundaban la capital filipina y que tomaba el nombre de un poblado situado en los arrabales de la capital. Al contrario que otros emplazamientos cercanos, como Bagumbaya, Quiapo o Longor, Santa Ana conservaba un carácter más agrícola y disociado de las dinámicas de Intramuros. Es por ello que, sus contemporáneos, lo trataron como un pueblo independiente, no apareciendo en el mapa de Manila y sus 
si los comparamos con los importantes movimientos que estaban sucediendo en estos momentos en la gobernación de Filipinas. La llegada hace unos pocos meses del gobernador Manuel de León había supuesto un profundo cambio en los organigramas políticos de una Manila que vivía sumida en el caos político, con sus dos últimos altos mandatarios encarcelados y con sus élites cercenadas y enfrentadas en intensas disputas internas. Así mismo, los sucesos de este barangay de la provincia de Tondo palidecen todavía más si los comparamos con los movimientos vividos en estos momentos en la región. Con una China enfrascada en una serie de alteraciones internas, que devendrían en una guerra civil tan solo tres años más tarde, afectando sensiblemente a un comercio filipino que se había visto forzado a buscar mercados alternativos en diferentes entrepôts indios e insulíndicos tras la fracasada apertura a los neerlandeses. ${ }^{3}$ Todo ello, por no hablar de su transcendencia en la historia global, en los grandes procesos y estructuras mundiales, en las múltiples interconexiones comerciales que cubrían el planeta y en los grandes flujos de plata que, con Filipinas como uno de sus núcleos vertebradores, unían a América, Asia, Europa y África. ${ }^{4}$

Los hechos acontecidos en Santa Ana, aunque discurran a escala local y en un pequeño poblado agrario de lo que durante muchos años se ha considerado la periferia de la Monarquía hispánica, nos muestran cómo el eco de los grandes procesos que se estaban desarrollando en esos momentos - regional y globalmente- también resonaron en este pequeño barangay. Por lo que sus habitantes, aunque posiblemente no eran conscientes de estas dinámicas, acabaron viéndose influenciados tanto por la creciente conexión intercultural que en estos momentos se estaba dando en el globo como por el incesante tránsito de personas, mercancías y mentalidades. De modo que podemos encontrar en este pequeño poblado muestras de una rica diversidad étnica y cultural, en la que chinos, indígenas filipinos de diversas procedencias, europeos y americanos con creencias y formas de vida distintas convivían conjuntamente, así como claros ejemplos de cómo las redes comerciales que circundaban el planeta habían conseguido adentrarse en este pequeño poblado, alterando los hábitos de consumo de sus habitantes y sus propias manifestaciones. Por tanto, el discurrir de los pobladores de este pequeño enclave filipino y sus historias individuales - fluyendo dentro un contexto

arrabales elaborado por Ignacio Muñoz en 1671, «Descripción geométrica de la ciudad y circunvalación de Manila y sus arrabales al Real Consejo de Indias», 1671, Archivo General de Indias, Sevilla (AGI), Mapas y Planos, Filipinas, 10.

3 Tremml-Werner, 2017. Schreurs, 1989.

4 Entre otros, Bonialian, 2012; 2021; Herrera Reviriego, 2016; Flynn y Giraldez, 1995. 
influenciado por la globalización — pueden ayudarnos, como ya hizo Tonio Andrade en sus estudios de «microhistoria global» enmarcados en Taiwán, ${ }^{5}$ a enriquecer las estructuras y procesos de la historia mundial, acercando perspectivas individuales o panorámicas locales a procesos con un mayor ámbito de influencia; al mismo tiempo que podemos apreciar cómo diversas tendencias acontecidas en una escala regional, nacional o continental influyeron en este espacio local, ${ }^{6}$ alterando sus formas de vida y añadiendo múltiples elementos distintivos. Todo ello, mientras intentamos vislumbrar, como hiciera Romain Bertrand para la Manila de 1577, la existencia de diversos «mundos» que coexistían y se entrelazaban en un mismo lugar. ${ }^{7}$

A pesar de que en el siglo XVII se encontraba a solo unos pocos kilómetros de la Manila intramuros, Santa Ana se mostraba casi completamente distanciada de las dinámicas manileñas, presentando unos tiempos y unas formas de vida independientes y ajenas del mundo urbano. ${ }^{8}$ De esta forma, los sucesos acontecidos en Santa Ana también nos otorgan una valiosa información acerca del ámbito local filipino y de sus regiones agrícolas, aportándonos una visión de la estructura jerárquica, de su producción agrícola, de sus formas de vida y de la estructuración poblacional de una comunidad de las lowlands de Luzón. ${ }^{9}$ Los testimonios que nos brindan gozan de un valor innegable pues, lamentablemente, mucha de la documentación de la época se ha perdido con el paso de los años, sobreviviendo fundamentalmente la relativa a las grandes problemáticas de la gobernación o a los

5 Andrade, 2011. Son numerosos los debates surgidos sobre el alcance, potencial y diversos aspectos teóricos de esta «microhistoria global», véase, entre otros, De Vries, 2019; Ghobrial, 2014; Levi, 2018; Trivellato, 2011.

6 «Como todos los historiadores, yo estoy ligado a los lugares y a los espacios particulares y mi saber es resultado directo de una formación en la lectura de textos, de archivos y de imágenes [...] La historia global no está destinada a sustituir la historia hecha a escala regional, nacional o continental, sino a complementarla [...] No es posible escribir una historia global desde ninguna parte». Subrahmanyam, 2014, 62-63.

7 «Hence, bridging the gap between microhistory and global history may not mean moving back and forth between different levels of contextualization, as if reality was a tiered, multi-layered cliff and the historian an adventurous alpinist, but rather unearthing the fossilized remains of the many worlds that lay intermeshed in one single location». Bertrand, 2019.

8 Este pequeño poblado nos presenta una visión diferente de la integración filipina en la globalidad a la que nos muestra Manila. La cual, como defendiera José Javier Ruiz Ibáñez para otros pequeños enclaves de la Monarquía, «puede resultar incluso más representativo por su naturaleza ordinaria, que los espacios de excepcionalidad que son las capitales o los brillantes, pero restringidos, grupos sociales que han atraído la atención de la historiografía reciente», Ruiz Ibáñez, 2014. En la actualidad, y debido al continuo crecimiento de la capital filipina, la pujante Manila ha acabado absorbiendo a Santa Ana, convirtiéndola en uno más de sus numerosos barangayes y borrando casi totalmente el carácter agrícola que gozaba en el siglo XVII.

9 Sobre los arrabales de Manila, véase Alva Rodríguez, 2014. 
procesos internos de Intramuros. Gran parte de la información disponible sobre el agro filipino procede de crónicas eclesiásticas, documentos datados inmediatamente después de la llegada de las armas hispánicas al archipiélago filipino u obras escritas durante los últimos compases de la presencia española en las islas, estando muchos de ellos centrados cronológicamente en los siglos XVI y XIX, por lo que las referencias relativas al XVII, y sobre todo a su segunda mitad, son realmente escasas. ${ }^{10}$ Además, mucha de esta documentación trata de aglutinar y homogeneizar las realidades de todo el medio agrícola filipino, así como las formas de vida de sus habitantes, cuestión que, además de difuminar la realidad local que nos ocupa, resulta una tarea casi imposible, sobre todo si tenemos en cuenta la elevada diversidad cultural, identitaria, religiosa y poblacional que se puede encontrar en las más de 7.000 islas que componen este archipiélago.

Así pues, vamos a intentar adentrarnos en los hechos acontecidos el 12 de marzo de 1670 en Santa Ana desde una doble perspectiva. Desde un acercamiento a las formas de vida de un pequeño pueblo filipino a través de un suceso extraordinario que, mediante la ruptura de la cotidianidad, nos ayuda a adentrarnos en su idiosincrasia, en su día a día, y a vislumbrar cómo sus pobladores se expresan y viven estas vicisitudes siguiendo los recursos de su cultura y época. ${ }^{11}$ Pero también destacando que este enclave no era una pieza aislada de su entorno, sino que, a pesar de su tamaño y condición, ${ }^{12}$ el fluido intercambio de personas, mercancías e ideas que supuso el proceso conocido como «primera globalización» ${ }^{13}$ había conseguido penetrar en este barangay, de modo que podría llegar a enlazarse con la «historia conectada», ${ }^{14}$ puesto que pueden encontrarse vínculos entre este pequeño asentamiento filipino y regiones tan distantes como Japón, México, Insulindia, la península ibérica o China, al mismo tiempo que se aprecia cómo diversos movimientos y dinámicas que tuvieron lugar en estos enclaves acabaron teniendo sus repercusiones en el día a día de este pequeño barangay filipino. De igual modo, los hechos acontecidos en Santa Ana acabaron teniendo su repercusión en la gobernación de Filipinas e, incluso, pudieron llegar a tener cierto eco en otras regiones. Por ejemplo, estos sirvieron al gobernador Manuel de León para reforzar su posición en las islas sobre

10 Huerta, 1855.

11 Pons y Serna, 2000.

12 McNeill y McNeill, 2004 2007.

13 Alfonso Mola y Martínez Shaw, 2014. Gunn, 2003. Martínez Torres, 2014. Subrahmanyam,

14 Entre otros ejemplos, Subrahmanyam, 1997; Brook, 2008; O’Brien, 2006. 
ciertas órdenes religiosas como los dominicos y los agustinos, mientras intensificaba su apoyo a los jesuitas, a quienes favoreció en regiones tan distantes como las islas Marianas o el archipiélago de las Sangir; mientras que también fueron una de las causas que propiciaron que el comerciante luso Juan Gómez de Paiva se trasladara hasta Cantón con grandes cantidades de plata para la compra de mercancías, en una época en que el trato entre Manila y esta urbe china se debatía entre el cierre y la apertura. ${ }^{15}$

\section{El terror de la noche}

La noche había caído finalmente sobre Santa Ana y la oscuridad cubría totalmente el poblado en esta noche de luna nueva. Desde el navío anclado en el río, un rumor empezó a crecer con el paso de las horas. Sus tripulantes se encontraban descontentos y hambrientos, y las conversaciones no paraban de subir de tono. Su nave había sido la única de las tres que habían partido desde el cercano puerto de Cavite que no había podido remontar la corriente del río, por lo que muchos de los marineros tendrían que pasar la noche al raso. Además, el pequeño champán ${ }^{16}$ se había embarcado sin víveres, ${ }^{17}$ pues la gobernación había decido no acometer su compra, por lo que su tripulación se encontraba hambrienta y desesperada, ${ }^{18}$ pues, si las condiciones de navegación no mejoraban, podían pasar varios días hasta alcanzar su destino en Lampón. ${ }^{19}$ Para llegar hasta este puerto aun tenían que remontar el río hasta la laguna de Bay y, de allí, dirigirse a través de

15 Herrera Reviriego, 2016.

16 Los champanes eran embarcaciones de tradición asiática ligeras y de pequeño calado. Fueron muy utilizadas en los mares de Filipinas durante el siglo XVII por chinos, japoneses e hispanos. Lamentablemente, las fuentes consultadas no nos muestran el nombre de la embarcación, su capacidad, el número total de sus tripulantes o algunos aspectos técnicos. De todos modos, el hecho de que diversos testimonios confundieran esta embarcación con un patache puede ser indicativo de que esta nave podía haber adoptado alguna modificación de tradición europea.

17 «Y que de no quererlo dar el sangley se le quitasse, por la necesidad que tenían de mantenimiento, por no averles dado ninguno al embarcarse, y que lo trujesen al champán». Testimonio de Antonio Vidal Serrano, Manila, 25 de marzo de 1670, AGI, Filipinas, 10, r. 1, n. 5.

18 «Diciendo que querían buscar que comer, porque no les avían dado». Testimonio de Antonio de Espíritu, Santa Ana, 13 de marzo de 1670, AGI, Filipinas, 10, r. 1, n. 5.

19 Lampón se constituyó durante los años centrales del siglo XVII como un puerto alternativo a Cavite para los galeones de Manila. Englobado en estos momentos en la provincia de Bay, poseía unas excelentes comunicaciones con el Pacífico y una conexión fluvial indirecta con Manila. Gracias a la riqueza maderera de la región y a su posición estratégica, diversos galeones acudieron hasta sus astilleros para ser reparados o preparados para los duros viajes transpacíficos. Aunque esta actividad pudo concentrar un importante número de trabajadores y mercancías en la región, lamentablemente, no disponemos de documentación suficiente para cuantificar el tráfico fluvial en el eje Manila-Bay-Lampón a mediados del siglo XVII. Sobre el puerto de Lampón, véase Baudot Monroy, 2020. 
escarpados caminos forestales hasta la costa oriental de Luzón. Asimismo, los ánimos entre los marineros podrían encontrarse caldeados desde su estancia en Cavite, pues, durante los últimos meses, se habían sucedido los impagos y retrasos por parte de la administración. Estos parecían que iban a continuar durante su estancia en Lampón ya que, en el momento de su partida, la gobernación aún se encontraba solicitando préstamos entre los comerciantes de Manila para poder costear el aderezo del galeón San Diego. ${ }^{20}$

El hecho de que la administración manileña no se hiciera cargo de la compra de los víveres pudo no ser un hecho puntual, ${ }^{21}$ sino la consecuencia de un problema mucho más profundo. La Hacienda de la gobernación de Filipinas se encontraba en 1670 ante una situación realmente delicada, ${ }^{22}$ pues sus fondos no habían dejado de caer durante los últimos años, afectados en gran medida por los desmanes y reformas fracasadas de sus dos últimos altos mandatarios, el gobernador Diego Salcedo y el oidor Manuel de Peña Bonifaz, ${ }^{23}$ a lo que se le tenía que unir el importante descenso que habían sufrido los situados que llegaban desde $\mathrm{México}^{24} \mathrm{y}$ los distintos problemas comerciales con los países circunvecinos. ${ }^{25}$ Por lo que el recién

20 Finalmente, el 22 de marzo de 1670, la gobernación autorizó el envío de mil pesos para socorrer a los trabajadores del puerto de Lampón, cifra bastante inferior a la que se solía destinar para el mismo concepto en Cavite. Informe de los gastos de la Gobernación en 1670, AGI, Filipinas, 10, r. 1, n. 3.

21 En 1666, la gobernación consiguió pagar parte de lo que se adeudaba a los trabajadores del puerto de Cavite gracias a que se expropiaron forzosamente - y en contra de la legalidad - 40.000 pesos a Manuel Suárez de Oliveira, comerciante portugués que en estos momentos se trataba de la persona más acaudalada de Manila. Informe de la incautación a Suárez de Oliveira, Manila, 1666, AGI, Filipinas, 43, n. 47. Para más detalles sobre la figura de Manuel Suárez de Oliveira, véase Lopes, 2019.

22 La estrechez presupuestaria continuó siendo muy dura hasta el año 1674. Durante este periodo se pidieron préstamos forzosos a algunos de los comerciantes más ricos de Manila, se incrementó el gravamen sobre las mercancías cargadas rumbo a México, se ampliaron los beneficios conseguidos del tributo indígena y se cargó con nuevos impuestos a la población de origen chino. Todo ello, mientras se realizaba un reajuste militar para reducir el importante gasto que tenía la gobernación en este apartado, llegando incluso a pagarse las soldadas de Manila y Cavite con carne en vez de con reales. Carta de Manuel de León, Manila, 15 de junio de 1671, AGI, Filipinas, 10, r. 1, n. 7. Carta de Manuel de León, Manila, 10 de junio de 1670, AGI, Filipinas, 10, r. 1, n. 4.

23 Desde 1668 a 1670 únicamente entraron en concepto de socorro a las arcas manileñas 130.000 pesos, cifra muy inferior a las recibidas en años anteriores. «Con 16.000 pesos halló las caxas reales quando entró a governar, a que se añadieron 75.000 pesos que trujo de socorro». Respuesta de un religioso anónimo a una consulta sobre la actuación de Manuel de León, sin fecha, Archivo de la Provincia Dominicana de Nuestra Señora del Santo Rosario, convento de Santo Tomás, Ávila (APSR), Historia Civil de Filipinas, t. 2, d. 7.

24 Carta de Manuel de León, Manila, 10 de junio de 1670, AGI, Filipinas, 10, r. 1, n. 1.

25 De 1669 a 1673 no llegó ningún navío desde la China continental hasta Manila. Por lo que el trato de los comerciantes chinos se trasladó hasta Taiwán y a otros entrepôts del continente asiático. Así mismo, el cese del comercio con los neerlandeses tras el encarcelamiento de Diego Salcedo en 1668 también supuso un menoscabo importante en el aprovisionamiento de productos asiáticos para su posterior venta en el mercado interior filipino y en el americano. Herrera Reviriego, 2016. 
llegado gobernador Manuel de León se vio forzado a desestimar el pago de muchas de las partidas presupuestarias, incluso las más pequeñas y urgentes, como la de la compra de los víveres para el champán que había dado fondo en Santa Ana. Huelga decir que a la tripulación del navío la situación económica de la gobernación y sus problemas mercantiles le importaban más bien poco. Ellos estaban hambrientos y, si no podían conseguir alimentos en su propio barco, lo harían fuera de él.

Los tripulantes de la embarcación, entre los que se encontraban indígenas filipinos procedentes de diversas de sus provincias como Pampanga, Panay o Bay, así como castellanos, portugueses ${ }^{26}$ mexicanos ${ }^{27}$ y colombia$n o s,{ }^{28}$ se reunieron con el cabo de la nave Domingo García, quien procedía de la península ibérica, y el capitán de la expedición, Manuel de Melo, quien, a pesar de que las fuentes no son claras al respecto, pudo tener un más que probable origen luso. ${ }^{29}$ Junto a ellos, presenciando toda la conversación, estaba María Orduña, una indígena nacida en la lejana isla filipina de Cebú, de tan solo 18 años, quien a pesar de su temprana edad estaba casada con Manuel de Melo, quien ya contaba con 59 años. ${ }^{30}$ Ante el peligro de que la tripulación pudiera amotinarse, Domingo García accedió a que algunos de los tripulantes saltaran a tierra y buscaran comida en el poblado. Incidiendo en que todos los víveres que se cogieran fueran debidamente

26 «Y vio este testigo desde lejos que hablaba con dicho portugués». Testimonio de Don Felipe de Santa Ana, Santa Ana, 14 de marzo de 1670, AGI, Filipinas, r. 1, n. 5.

27 «Vio en el patio de su convento a un español que dijo era gallego, preguntándole dicho padre de donde era amarrado, y otro que a su parezer era mexicano, y otros quatro indios amarrados asi messmo». Ibidem.

28 «Y dijo ser natural de Cartagena de las Indias». Testimonio de Diego Muñoz, Manila, 25 de marzo de 1670, AGI, Filipinas, 10, r. 1, n. 5.

29 Todos los participantes en el proceso son preguntados por su origen al final de sus testimonios, detallándose su ciudad de nacimiento y/o región, excepto en los casos de Manuel de Melo y de Juan Gómez de Paiva. Ambos personajes contaban con raíces portuguesas, como se plasma en otros documentos y como se muestra en los reiterados contactos que tuvieron estos personajes con diversos entrepôts lusos durante la salida comercial manileña de la década de 1650. Informe sobre el registro de los navíos llegados a la Gobernación, AGI, Filipinas, 11, r. 2, n. 14. Además, el ocultamiento de las raíces lusas de importantes miembros de la sociedad manileña, completamente aculturalizados e insertos en ella, era una práctica bastante común en las Filipinas del siglo XVII. Así ocurrió con varios personajes como Manuel Suárez de Oliveira o Pedro Porto, de quienes no se desvela su origen luso hasta que se vieron envueltos en problemas directos con la Inquisición o con la Audiencia. Autos de la Audiencia sobre el empréstito exigido a Manuel Suárez de Oliveira, Manila, 25 de noviembre de 1666, AGI, Filipinas, 23, r. 8, n. 22. Testimonio de Sebastián Rayo Doria ante la Inquisición de Filipinas, Manila, 4 de septiembre de 1668, Archivo Histórico Nacional, Madrid (AHN), Inquisición, 1729, exp. 11.

30 «Y declaró ser de diez y ocho años poco más o menos, y que, aunque muger del dicho Manuel Melo, no por esso a dejado de dezir la verdad». Testimonio de María Orduña, 12 de abril de 1670, AGI, Filipinas, 10, r. 1, n. 5. 
pagados, pero que, en caso de que sus habitantes no accedieran a venderlos, se arrebataran por la fuerza. ${ }^{31}$ Los elegidos para esta misión fueron algunos marineros de origen español y mexicano, encabezados por Bernardo Curiel, diversos indígenas de los astilleros y un grumete de corta edad.

Este pequeño grupo, amparado por la oscuridad de la madrugada, embriagado por la superioridad que le otorgaba su número y con los ánimos caldeados por el malestar vivido en sus jornadas de navegación, irrumpieron en Santa Ana y se dirigieron a la casa más cercana al río. En ella dormía plácidamente Domingo de Ramos, manileño que, a pesar de su origen africano, ${ }^{32}$ hablaba el castellano. ${ }^{33}$ Junto a él descansaba el pampango Diego de Catacotar, quien se había quedado en casa de su amigo tras ayudarle en las labores de su campo de maíz por la incomodidad de tener que cruzar el río que serpenteaba por toda Santa Ana para retornar a su domicilio. ${ }^{34}$ Los marineros, sin mediar palabra con Ramos, rompieron la cerca que circundaba su morada, llevándose todo el arroz y el maíz que encontraron, así como varias gallinas y un gallo. Pero el pillaje de los miembros de la embarcación no quedó aquí, sino que también se llevaron un sombrero del campesino africano y la guitarra que horas antes sonaba en manos del pampango, sin que ninguno de los dos se atreviera a impedírselo, pues los marineros portaban con ellos grandes cuchillos y otras armas blancas. ${ }^{35}$

31 «El dicho cavo Domingo García les dijo a dichos marineros y a cinco o seis indios pandais, saltassen en tierra y buscasen algún arroz y tres o quatro gallinas y que se pagasse su valor. Y que de no quererlo dar el sangley, se le quitasse por la necesidad que tenían de mantenimiento, por no averles dado ninguno al embarcarse, y que lo trujesen al champán que él lo ajustaría con el sangley». Testimonio de Antonio Vidal Serrano, Manila, 25 de marzo de 1670, AGI, Filipinas, 10, r. 1, n. 5.

32 Aunque existía un considerable número de esclavos africanos en Filipinas, llevados hasta las islas principalmente por portugueses, también existía una importante población libre o liberta, quienes por Real Cédula de 1635 debían vivir en una isla junto a Santa Cruz. La presencia de Domingo de Ramos en Santa Ana nos muestra que la población africana pudo extenderse por gran parte de las lowlands de Tondo y no únicamente por el enclave designado por la normativa regia. «Para la seguridad de ella combiene salgan de esta ciudad los morenos libres, libertos [...] señalo por puesto a donde perpetuamente bivan la ysla de los padres de la Compañía de Jesús que por una parte mira al Parián de los sangleyes de esta ciudad y por otra al pueblo de Santa Cruz». Real Cédula de 29 de septiembre de 1635, APSR, Historia Civil de Filipinas, t. 2, d. 2.

33 «A un moreno criollo de Manila, ladino lo bastante en castellano que no necesitó de ynterprette». Testimonio de Domingo de Ramos, 13 de marzo de 1670, AGI, Filipinas, 10, r. 1, n. 5.

34 «ste testigo en la casa de Domingo de Ramos que está en la otra banda de este dicho pueblo, con ocasión de que avía ydo a guardar la sementera de maises». Testimonio de Diego de Catacotar, Santa Ana, 14 de marzo de 1670, AGI, Filipinas, 10, r. 1, n. 5.

35 «Que les escuadriñaron la dicha casa y les sacaron de ella un poco de arroz [...] siete pollos, un gallo y un sombrero negro de dicho Domingo de Ramos y una guitarrilla de este testigo. Y les vio en las manos algunas armas como machetes carniceros y garrotes, por cuía razón este testigo y el dicho Domingo de Ramos no rresistieron el rrobo, que les hacían temerosos de que no los matasen». Testimonio de Diego Catacotar, Santa Ana, 14 de marzo de 1670, AGI, Filipinas, 10, r. 1, n. 5. 
Tras estos hechos, los asaltantes penetraron tierra adentro, dividiéndose en varios grupos y dejando a sus espaldas la casa de Domingo de Ramos y el convento de Santa Ana. Uno de ellos se dirigió hacia la casa del cabeza de barangay, Antonio de Espíritu, ${ }^{36}$ quien, tras haber acabado su jornada de pesca, había salido de su casa en dirección al río tras escuchar gritos y ruidos sospechosos procedentes de esta zona. Los marineros se encontraron la casa con poca vigilancia, quedando en ella únicamente Florentina de la Cruz, mujer de Antonio, un esclavo indígena llamado «Pablico», ${ }^{37}$ quien se encontraba en el patio limpiando arroz, y un mestizo de español llamado Ignacio Montes Doca. Tras haberse llenado los zurrones de arroz y gallinas en la anterior casa, los marineros encontraron una pieza mucho más apetecible que llevarse a la boca en casa del noble filipino: un carabao. Estos búfalos de agua eran un elemento principal dentro del mundo agrícola filipino, ${ }^{38}$ así como una pieza indispensable para el trabajo en los campos inundados de arroz del sudeste asiático, por lo que no es de extrañar que tanto Montes Doca como «Pablico» suplicaran a los intrusos que lo dejaran con vida e intentaran negociar con ellos, ofreciéndoles todas las gallinas y arroz que tenían en casa a cambio de que no mataran al animal, ${ }^{39}$ a lo que finalmente accedieron posiblemente por lo problemático del despiece del carabao y las dificultades de su transporte hasta el champán.

Mientras tanto, el otro grupo de marineros se encaminó a una pequeña casa con la techumbre de nipa ${ }^{40}$ no muy alejada de la rivera del Pasig. En

36 Sobre las principalías indígenas, su colaboración con las autoridades manileñas y su papel en sus comunidades, véase Alonso Álvarez, 2005; Fernández Palacios, 2019; Sánchez Gómez, 1989.

37 La esclavitud de indígenas en manos de otros filipinos o mestizos de sangley era una práctica enraizada culturalmente y bastante común en el archipiélago durante gran parte de la Edad Moderna. Esta difería sensiblemente de la esclavitud que se desarrollaba en Europa, América y otros enclaves asiáticos, ofreciendo mejores condiciones de vida a las personas privadas de libertad. Prieto Lucena, 1993.

38 La importancia de este animal en el agro filipino se puede apreciar en las palabras de Francisco Cañamaque y Jiménez de 1877: «No se comprende al indio sin el carabao ni a este sin aquel. Se buscan, se encuentran y se completan. Encima del carabao hace el indio sus viajes, el carabao labra sus tierras, con el carabao crecen sus hijos, el carabao le transporta los efectos y las cargas, el carabao le acompaña a todas partes, junto al carabao duerme y a su lado come, huelga y vive». Cañamaque Jiménez, 1877.

39 «Intentó uno de ellos matar un carabao de este testigo. Y rrogándoles con el dicho Ygnacio no los matasen, que les darían de comer a todos, los dejaron y se fueron». Testimonio de Antonio de Espíritu, Santa Ana, 13 de marzo de 1670, AGI, Filipinas, 10, r. 1, n. 5.

40 Las casas de caña y nipa fueron una constante en la tradición arquitectónica filipina, en parte debido a que las construcciones en piedra se mostraron sumamente inseguras en una zona tan proclive a las sacudidas tectónicas como es Luzón. Es más, la iglesia de Santa Ana estuvo construida a partir de estos materiales hasta 1720 , fecha en que se iniciaron las obras de una nueva fabricada en piedra. Huerta, 1855 
ella vivía un joven matrimonio compuesto por una mestiza de sangley llamada Florentina de la Cruz, ${ }^{41}$ de tan solo 16 años, ${ }^{42}$ y su marido de origen chino Jacinto Suco, quien ejercía de labrador en el poblado trabajando sus propias tierras. Los marineros rompieron violentamente la cerca que circundaba la casa, mientras cogían todo el arroz y gallinas que encontraron a su paso, así como rábanos y mostaza salada que se utilizaba de condimento en la cocina. Florentina y su marido se levantaron sobresaltados ante el ruido de los animales y los gritos en castellano que procedían del exterior; para cuando quisieron darse cuenta, los marineros del champán ya estaban en el interior de su casa. Una vez dentro, parte del grupo se dedicó a saquear los enseres de la pareja, robándoles mantas, ropa de cama, algunas prendas de vestir de Florentina y dejando a Jacinto únicamente con lo que llevaba puesto. ${ }^{43}$ Pero los tripulantes del champán no se limitaron a robar las pertenencias de la pareja, sino que algunos de sus miembros intentaron agredirles físicamente. Jacinto Suco llegó a temer en varios momentos por su vida, escondiéndose detrás de su mujer en un acto de innegable cobardía. Mientras que, por su parte, Florentina hacía todo lo posible para zafarse de un español que no dejaba de abrazarla con la intención de violarla, y al que la penumbra de la noche no dejó identificar. ${ }^{44}$ La mestiza de sangley no cesó de gritar pidiendo ayuda en todo momento a pesar de las amenazas de los asaltantes ${ }^{45}$ y fue precisamente esto lo que salvó a Florentina de las perversas intenciones del marinero, pues alarmados ante el estruendo que llegaba desde su casa, varios de sus vecinos llegaron en su auxilio. ${ }^{46}$

41 No confundir con la mujer de Antonio de Espíritu con la que compartía nombre y apellidos, pero no raíces familiares ni étnicas.

42 La edad de Florentina de la Cruz es puesta en duda por sus interrogadores, puesto que, aunque ella declara que tenía 16 años, se apunta a que posiblemente tenía veinte años o más. «Firmó, y ratificó y declaró ser de diez y seis años, y por su aspecto tener veinte». Testimonio de Florentina de la Cruz, Santa Ana, 13 de marzo de 1670, AGI, Filipinas, 10, r. 1, n. 5.

43 «Le avían abiertto una caxa llevándole de ella una saya negra, una cambaya, dos chininas labradas, dos naguas blancas de manta y la rropa de vestir de su marido, sin dejalle más de lo que tiene ensima». Testimonio de Florentina de la Cruz, Santa Ana, 13 de marzo de 1670, AGI, Filipinas, 10, r. 1, n. 5 .

44 «Vio relumbrar como carnizeros y con dichos amagos la izo a entender que la quería gozar, porque la abrasava y esta teestimonio se rresistió, levantándose también su marido que la ponía por delante, temeroso porque no le matasen». Idem.

45 «Que quando la dicha mujer llamava a grittos al padre, le deçían en lengua castellana: calla la boca porque si no te emos de matar». Testimonio de José de la Cruz, Santa Ana, 13 de marzo de 1670, AGI, Filipinas, 10, r. 1, n. 5.

46 «Oyó gritos al parezer de mujer que lengua tagala dezía que la matavan y la acudiesen llamando también al padre y el dicho sangley dezia ayá». Testimonio de Antonio de Espíritu Pagcaliuagan, Santa Ana, 13 de marzo de 1670, AGI, Filipinas, 10, r. 1, n. 5. 
Los marineros se vieron completamente rodeados en poco tiempo por un heterogéneo grupo compuesto por muchos de los habitantes de Santa Ana, como Antonio de Espíritu, su hermano José de la Cruz, quien se había topado la mañana anterior con los tripulantes del champán junto al Parián de los sangleyes ${ }^{47}$ Ignacio Montes Doca o el principal, Felipe de Santa Ana. Todos ellos se encontraban armados con lo que habían encontrado a mano en sus casas; los más humildes con garrotes y remos de canoas, mientras que los más pudientes del poblado, como Antonio de Espíritu y el gobernadorcillo Jacinto del Rosario, lo hacían con afiladas catanas japonesas y sólidas rodelas. ${ }^{48}$ Encabezándolos se encontraba el religioso agustino Pablo de la Visitación, natural del municipio castellano de Barco de Ávila ${ }^{49}$ y encargado de la doctrina del pueblo, blandiendo una espada y un escudo propiedad de Ignacio Montes Doca. Este eclesiástico tuvo un papel muy importante en la formación de la hueste, arengando a los vecinos de Santa Ana a atrapar a los miembros de la tripulación con las siguientes palabras en tagalo: «síganlos y prendalos y si se rresisten denles de palos y amárren$l o s{ }^{50} \mathrm{o}$ «maten a estos pícaros, a estos ladrones» ${ }^{51}$ La agresiva respuesta del agustino se puede contextualizar en el hecho de que este acababa de llegar hasta Santa Ana desde Camarines, provincia que se había visto envuelta en una espiral de violencia durante las últimas décadas por culpa de la piratería procedente de los badjaos y de los sultanatos meridionales de Joló y Mindanao. Por lo que, posiblemente, no habría sido la primera incursión de pillaje que habría vivido este abulense en su jurisdicción y su reacción se ajustaba a las medidas de autoprotección que pudo observar en Camarines debido a la escasa presencia militar de las armas hispánicas en esta región.

La noche tocaba a su fin y los ánimos estaban más encendidos que nunca pues, a los desmanes que habían llevado a cabo los marineros en el poblado, se le unía el hecho de que se había esparcido el rumor en el poblado de que los asaltantes habían asesinado a Francisco de Barajas, padre guardián del pueblo, que en estos momentos superaba los sesenta años y

47 El Parián de los sangleyes o Alcaicería era un barrio extramuros de Manila en el que se concentraba gran parte de la población china de las islas. En él se podían encontrar artesanos, comerciantes y mercancías de todo tipo, siendo un importante foco de actividad económica.

48 «Y el dicho gobernador con una catana de Japón envainada en la sinta, su bara gruessa en una mano, y una rrodela de bejuco que llevaba un bilango suyo». Testimonio de Felipe de Santa Ana, Santa Ana, 14 de marzo de 1670, AGI, Filipinas, 10, r. 1, n. 5.

49 Lista de religiosos agustinos destinados a Filipinas, 1653, AGI, Filipinas, 81, n. 37.

50 Testimonio de José de la Cruz, Santa Ana, 13 de marzo de 1670, AGI, Filipinas, 10, r. 1, n. 5.

51 Testimonio de Lucas de Pina, Manila, 13 de marzo de 1670, AGI, Filipinas, 10, r. 1, n. 5. 
que a duras penas podía aguantarse de pie sin su bastón. ${ }^{52}$ De modo que, lo que empezó como un intento por salvar a Florentina de la Cruz y repeler a los intrusos, con las primeras luces del día acabó convirtiéndose en una violenta refriega.

\section{Amanece en Santa Ana}

Con la luz del alba resplandeciendo débilmente sobre las llanuras de Tondo, los marineros huyeron despavoridos hacia el champán. Los vecinos de Santa Ana les superaban ampliamente en número y estaban mejor preparados para una refriega que ellos. En su desbandada, alzaron desesperadamente sus voces hacia sus compañeros que permanecían en la embarcación, pidiendo que bajaran a auxiliarlos y les facilitaran el abordaje.

Al ver a sus hombres en peligro de muerte, Domingo García, el cabo de la embarcación, cogió una espada que pertenecía a Manuel de Melo y saltó a tierra junto a algunos de los marinos. Su intento por salvar a su tripulación no fue en vano, y la gran mayoría de los marineros consiguieron llegar sanos y salvos hasta el champán, pero el propio Domingo García no tuvo tanta suerte y acabó cayendo en la refriega. Según el testimonio de sus hombres, el cabo de la embarcación murió a manos de Antonio Espíritu, quien le asestó un fuerte golpe en la cabeza con la parte roma de una lanza, dejándole tan aturdido que cayó inconsciente al agua y fue arrastrado por la corriente río abajo. ${ }^{53}$ Su cadáver no fue encontrado sino hasta varios días después, hinchado y completamente amoratado, flotando en la ribera del Pasig aledaña a la capital. Su cuerpo fue trasladado hasta el Real Hospital de Manila donde, a pesar de que se constató que no presentaba heridas visibles, no se pudo establecer las causas de la muerte por encontrarse el cadáver del cabo completamente desfigurado y en un avanzado estado de descomposición. ${ }^{54}$

52 Carta de Antonio de Somoza, 19 de septiembre de 1672, AGI, Filipinas, 86, n. 32.

53 «Vio este declarante salir de través a un indio ladino, que oyó le llamavan los demás capitán Don Antonio Espíritu, con una lança, siguiendo a todo correr al dicho cavo Domingo García, que yva a arrojarse al agua y que le dio amateniente con él, hasta de la lança a dos manos tan gran golpe en la cabeza que atordido, el caió al agua por cogerle a la orilla, y que este declarante no lo volvió a ver más [...] de que tiene por cierto se ahogó por esta causa». Testimonio de Antonio Vidal Serrano, Manila, 25 de marzo de 1670, AGI, Filipinas, 10, r. 1, n. 5.

54 «Y aviéndole descosido la dicha mortaja no pareció tener heridas algunas, ni señal, de golpe, ni distinguir ni conocer quien pudiera ser ni llamarse en vida, por estar disfigurado y todo el cuerpo hinchado y moreteado desde la cabeza a los pies. Que de ninguna manera se podía conocer, y sólo al volverlo de un lado a otro, echava sangre por las narizes [...] Que el dicho difuntto se llamaba en vida Domingo García, marinero en sueldo de su magestad, y que yba al puerto de Lampón». Testimonio de Nicolás de Herrera, 16 de marzo de 1670, AGI, Filipinas, 10, r. 1, n. 5. 
Misma suerte corrió el español Bernardo Curiel, ${ }^{55}$ quien todavía se encontraba dentro de la casa de Florentina de la Cruz y Jacinto Suco cuando esta fue rodeada por los vecinos de Santa Ana. Una vez advertida su presencia, fue arrastrado hasta el exterior donde fue apaleado por la exaltada muchedumbre, acabando con su vida de una estocada en el costado que le atravesó el cuerpo de lado a lado. ${ }^{56}$ Su cadáver fue arrojado al río Pasig y llevado por la corriente, siendo encontrado días después atascado bajo uno de los ojos del puente del vecino pueblo de Rosario. Como pasó con el cabo Domingo García, la identificación de su cuerpo fue realmente complicada debido a su mal estado de conservación, siendo posible su reconocimiento gracias únicamente a una malformación en el pie derecho que hacía que dos de sus dedos se encontraran pegados. ${ }^{57}$

Además de Domingo García y Bernardo Curiel, también perdió la vida en la escaramuza uno de los marineros indígenas que iban a bordo del champán. Pero, al contrario de los casos anteriores, las fuentes no profundizan en este y no detallan su nombre, procedencia u otros datos de interés, aludiendo únicamente a que murió de un machetazo en la cabeza. Incluso, el escribano público de número de Manila, Nicolás de Herrera, encargado de informar sobre las autopsias de los difuntos, omitió cualquier detalle sobre la muerte de este indígena, aunque él mismo contaba con orígenes pampangos. ${ }^{58}$

Otros miembros de la tripulación también resultaron gravemente heridos a pesar de poder alcanzar la embarcación. El grumete Mateo de Espinosa, indígena nacido en la provincia de Laguna de Bay, sufrió diversas contu-

55 Las fuentes no detallan su procedencia exacta, definiéndolo únicamente como «español», palabra que en Filipinas era usada indistintamente para designar a personas procedentes de otras regiones de la Monarquía, aunque principalmente de la península ibérica y América, fuera cual fuera su origen racial.

56 «Sercaron a Bernardo Curiel con grandes vozes en su lengua, dándole muchos palos, a que el susso dicho se yba retirando por no tener arma ninguna y que se arrimó a la cerca que el sangley hortelano tenía en la sementera. Y que allí con una de las armas que llevaban, le atravesaron de parte a parte, de que caió llamando en su ayuda la virgen santíssima, y tendido en tierra no le oyó hablar más». Testimonio de Antonio Vidal Serrano, Manila, 25 de marzo de 1670, AGI, Filipinas, 10, r. 1, n. 5.

57 «Y entando en el postigo de él que cae así al rrío, vi a un hombre tendido sobre un lancape, muertto y pasado de esta presente vida. El qual ni se pudo distinguir ni conocer quien fuesse en vida por estar inchado y desfigurado de la sintura para arriba. Mas de que al parezer era español, y viéndole todo el cuerpo, pareció tener una herida debajo del brazo derecho, que según dijo Blas Núñez de Prado, médico de dicho hospital Real, era de estocada, y volviéndoles de un lado a otro pareze tener las espaldas apaleadas según lo demostraban las señales. Y un soldado de los que vinieron con las llaves para abrir el postigo de dicho hospital dixo que el dicho difunto era de su vacada, y que se llamaba Bernardo Gudiel. [sic] Y que lo conocía por los dos dedos, segundo y terçero del pie derecho pegados». Testimonio de Nicolás de Herrera, 16 de marzo de 1670, AGI, Filipinas, 10, r. 1, n. 5.

58 Testimonio de Blas de Rosales sobre Nicolás de Herrera, Manila, 24 de junio de 1688, AGI, Filipinas, 23, r. 8, n. 30. 
siones debido a los múltiples golpes que le propinaron en el torso, así como una herida en la cabeza por el impacto de una lanza, arrojada por un mulato, y que necesitó de cinco puntos de sutura. ${ }^{59}$ Juan Longas, indígena de Bacolor, presentaba una fuerte herida en el antebrazo que, según su testimonio, fue producida por el propio padre Pablo de la Visitación. ${ }^{60}$ Otros miembros de la expedición tenían golpes y moratones por todo el cuerpo, pero que, a pesar de su aparatosidad, no presentaban mayores complicaciones médicas.

No obstante, no todos los marineros consiguieron subir a tiempo a la embarcación, pues ante las pedradas que incesantemente llovían desde la ribera, el champán salió de los límites del poblado sin reparar en si algunos de sus integrantes se habían quedado en tierra. Atrás quedaron varios hombres, como el mexicano Antonio Vidal Serrano, quien se había escondido en unos cañizos, el venezolano Juan Gallegos, que se había quedado inconsciente durante la refriega ${ }^{61}$ así como cuatro indígenas, dos de ellos tinteros y los otros dos herreros de profesión. Sin lugar donde refugiarse, los seis hombres fueron fácilmente capturados, atados de pies y manos y llevados hasta la cárcel del poblado.

Mientras tanto, los marineros que continuaban en el navío, presos del pánico y al carecer de cabo que dispensara otras órdenes, decidieron dar marcha atrás y emprender viaje de vuelta a Manila. Pablo de la Visitación, al ver que abandonaban el poblado dejando atrás a los compañeros, se acercó hasta la orilla del río, y allí les propuso un trato: se reunirían en la huerta de María Barandoa, que se encontraba en los límites de Santa Ana, y allí realizarían el intercambio de los cautivos por los bienes robados a los miembros del poblado. Los miembros del champán aceptaron, ${ }^{62}$ asegurando

59 «Y que temeroso se quizo arojar al agua y que a esta sazón, un mulato que no sabe su nombre que vive en dicho pueblo de Santa Ana, que conoce y sabe su casa, le tiró con una lanza y le alcansó en medio de la cabeza, una herida de tres dedos de largo, que aún no está del todo sana, que dicho arráez le curó y dio cinco puntos. Que la señal ha visto y también los cardenales que tiene en las espaldas y junto al estómago que lo tiene hinchado todavía de los golpez que indican le dieron». Testimonio de Mateo de Espinosa, 26 de marzo de 1670, AGI, Filipinas, 10, r. 1, n. 5

60 «stava pegado con la tierra, de inprovisso le tiraron un golpe que reparó con el braso derecho, y en la muñeca por la parte de abajo. Al soslayo le dieron una herida de dos de dos de ancho, según la señal que tiene. Y que al volver el rostro vio ser el padre, el que la avía dado». Testimonio de Juan Longás, 26 de marzo de 1670, AGI, Filipinas, 10, r. 1, n. 5

61 «Llegó uno de ellos que no conoce, y le dio en la cabeza de lleno con un machete largo. Tan gran golpe que le aturdió y se le dejó sin sentido. Y que al caer le agarraron los indios y amarraron atrás las manos y brasos». Testimonio de Juan Gallegos, Manila, 25 de marzo de 1670, AGI, Filipinas, 10, r. 1, n. 5.

62 «Y que no atreviéndose ninguno a saltar en tierra a hablar con dicho padre, este declarante se ofreció, y fue a pedirle cumpliesse la palabra de darles a sus compañeros, que de no hacerlo yría a Manila a dar parte de lo subcedido». Testimonio de Diego Muñoz, Manila, 25 de marzo de 1670, AGI, Filipinas, r. 1, n. 5. 
que, si no devolvían a los cautivos, acudirían a la justicia de Manila, acordando verse en unas horas, cuando el reloj marcara la cinco de la tarde y el sol bañara completamente el poblado.

El tiempo que los padres agustinos ganaron entre el asalto y la entrega de los presos sirvió para conseguir un doble objetivo: calmar los ánimos de los vecinos y exhibir la preeminencia de la Iglesia. Así pues, como se hiciera en Manila tras las victorias militares de Sebastián Hurtado de Corcuera sobre los sultanatos meridionales o en otras grandes ciudades de la Monarquía tras importantes triunfos de las armas hispánicas, los vencidos fueron exhibidos en público, amarrados y humillados por las calles de Santa Ana. ${ }^{63}$ En su tránsito, fueron llevados hasta la iglesia del poblado, donde los padres agustinos celebraron una misa de hora y media de duración, en la que los cautivos permanecieron a la vista de todos los feligreses, atados, arrodillados y llenos de fango ${ }^{64}$ Esta exhibición de los vencidos pudo responder a múltiples motivaciones como la de exaltar la victoria alcanzada, reforzar los lazos de la comunidad mediante el enaltecimiento de una empresa conjunta o demostrar la superioridad de la Iglesia sobre el poder de la gobernación, ya que — no olvidemos - los marineros se encontraban trabajando para el gobierno de Manila cuando ocurrieron los hechos. Este último punto se tiene que enmarcar en las numerosas fricciones que estaban viviendo las relaciones entre los miembros de la Audiencia y los cargos eclesiásticos en años recientes, sobre todo tras el encarcelamiento del gobernador Diego Salcedo por parte de la Inquisición.

Tras la exhibición pública de los cautivos, Francisco de Barajas, Juan de la Visitación y otros de los protagonistas del incidente, como la mestiza Florentina de la Cruz, el africano Domingo de Ramos o Antonio de Espíritu, se reunieron con los miembros del champán a la hora acordada. Junto a ellos iba un hombre que, si atendemos a su trayectoria anterior, menos esperaríamos ver en el pequeño poblado de Santa Ana: el capitán Juan Gómez de Paiva.

Este portugués, ${ }^{65}$ establecido desde hacía décadas en territorio filipino, había tenido una gran importancia en la vida política y económica del

63 «Divididos a Juan Gallegos ya Antonio Çerrano, marineros españoles. Sin sombrero, mojados y llenos de lodo, amarrados los braços y manos atrás a vista de todos». Idem.

64 «Y por medio del pueblo, y a vista de todos, los llevó hasta la puerta de la iglesia, donde se estaba diciendo missa, teniéndolos como ora y media a la vergüenza». Testimonio de Antonio Vidal Serrano, Manila, 25 de marzo de 1670, AGI, Filipinas, 10, r. 1, n. 5.

65 «El capitán Juan Gómez de Payva, de nación portugués y avecindado en esta ciudad». Carta de Juan Bolívar y Cruz, Manila, 19 de julio de 1655, AGI, Filipinas, 22, r. 7, n. 25. 
archipiélago durante los gobiernos de Diego Fajardo y Sabiniano Manrique de Lara, siendo protagonista en algunos de los sucesos que marcaron el devenir de las islas entre 1644 y 1663 . Gómez de Paiva fue uno de los promotores y precursores de la salida comercial manileña, proceso que puso en contacto directo a diversos vecinos de la gobernación con otros puertos mercantiles del continente durante la crisis vivida por el comercio chino como consecuencia del ocaso de la dinastía Ming. Entonces realizó repetidos viajes con sus propias embarcaciones hasta el entrepôt de Macassar, en Sulawesi ${ }^{66}$ y la ciudad china de Cantón, así como a la urbe portuguesa de Macao. Su faceta como comerciante le reportó una vida acomodada, así como una cierta reputación social que le permitió emparentarse con la familia Barandoa e ir escalando dentro del cursus honorum manileño a pesar de su origen luso. De este modo, consiguió alzarse rápidamente con el cargo de capitán de una compañía de infantería, tocando techo durante los últimos compases de la década de 1650 cuando alcanzó uno de los títulos de mayor importancia dentro del organigrama político de las islas: la alcaldía mayor de la Pampanga. Este cargo permitía a su poseedor adquirir una gran cuota de poder, pues esta provincia era una de las más ricas del archipiélago y, junto a Tondo, Bay y Bulacán, la que presentaba un mayor nivel de penetración de la cultura y tradiciones hispánicas. ${ }^{67}$ En consecuencia, su control podía otorgar a su alcalde mayor unas más que interesantes posibilidades de negocio, como ya habían demostrado sus antecesores en el cargo. Y es que Gómez de Paiva no fue el primer luso en ostentar este título, ya que anteriormente había sido ocupado por diversos portugueses con estrechas vinculaciones con el comercio internacional, como Antonio Báez de Acevedo o Andrés Cueto, quienes pudieron aprovechar sus contactos y su posición para introducir mercancías insulíndicas en la Pampanga ${ }^{68}$

Sin embargo, fue precisamente la obtención de este cargo lo que iniciaría la caída en desgracia de Juan Gómez de Paiva, pues bajo su mandato tuvo lugar la gran revuelta de la Pampanga de 1660, movimiento de gran

66 Sánchez Pons, 2020.

67 Larkin, 1993. Phelan, 1967. Fernández Palacios, 2014.

68 Así se desprende del registro de los bienes que Báez de Acevedo poseía en la provincia, y entre los que se podían encontrar grandes cantidades de textiles de procedencia insulíndica, posiblemente destinados al mercado interior filipino. «Ciento y setenta y quatro malagatas blancas de a doce baras con sesenta crudas. Ciento y cinco Talingas. Sesenta y Cinco Çarampures. Treinta y quatto mantas de a diez baras. Una pieza de gasa de a catorce baras. Cinquenta y nuebe caniquies finos y entrefinos. Ciento y veinte y nueve gasas finas de a diez y seis baras. [...] Veinte y nueve caniquies finos de a diez baras». Registro de los bienes confiscados a Antonio Baez de Acevedo, 12 de agosto de 1647, AHN, Inquisición, 4812, exp. 1. 
seguimiento en la provincia que acabó extendiéndose por otras regiones como Pangasinán y Bulacán, y que supuso un momento crítico para la pervivencia de la presencia hispánica en las islas ${ }^{69}$ La gestión de la crisis superó las habilidades del luso, pues no pudo detener su expansión en sus fases iniciales ni su propagación por otros territorios, siendo incluso sitiada su propia casa durante gran parte de la revuelta. ${ }^{70}$ Por lo que no es de extrañar que, una vez sofocada la rebelión, Gómez de Paiva fuera depuesto del cargo de alcalde mayor, siendo sustituido por el general Francisco de Atienza Ibáñez, quien presentaba un perfil más adecuado que el comerciante luso. ${ }^{71}$ Se acababa así con la presencia de mercaderes portugueses al frente de esta provincia y con sus esperanzas personales de seguir escalando en el sistema de cargos de la gobernación.

$\mathrm{Su}$ ascendiente se recuperaría brevemente durante el mandato del siguiente gobernador, Diego Salcedo, quien, a pesar de mantener pactos secretos con las Provincias Unidas, confió en Gómez de Paiva para estrechar lazos y abrir trato con el puerto de Cantón, enviándole hasta la costa china en una embarcación cargada con más de 100.000 pesos de diferentes vecinos de Manila para la adquisición de mercancías. Esta empresa acabó en un sonoro fracaso, pues lo que iba a ser un viaje de tres meses acabó dilatándose tres años, retornando a Filipinas sin haber conseguido sus objetivos iniciales ante el desconcierto de los inversores. ${ }^{72}$ Tras estos hechos, el portugués pasó a ocupar el cargo de capitán de una pequeña compañía de infantería en el puerto de Cavite, un título de nula importancia si tenemos en cuenta el prestigio alcanzado en el pasado. ${ }^{73}$ No es de extrañar que en 1670 Juan Gómez de Paiva se encontrara en una situación económica muy delicada, pues seguía contando con elevadísimas deudas pendientes con la

69 Polanco, 2004. Corpuz, 2005. Renato, 1976.

70 Carta de Sabiniano Manrique de Lara, Manila, 20 de julio de 1661, AGI, Filipinas, 9, r. 2 , n. 34

71 Francisco Atienza Ibáñez desempeñó durante estos años importantes tareas dentro de la Gobernación filipina, destacando su actuación durante las revueltas indígenas de la década de 1660 y su papel como diplomático durante las crisis vividas en Joló en 1646 y con los neerlandeses presentes en Ternate en 1662.

72 «n el año 64 hizo fabricar [un navío] y le despachó al reyno de Cantón en China a cargo de un capitán portugués, Juan Gómez de Payba [...] Haviendo en él suyos y de más particulares más de 100.000 pesos para emplear en Cantón y sien[do] viage de tres meses, a más de tres años que no se sabe de él. Y se tiene por cierto haverse perdido o cogido el enemigo inglés». Carta de Miguel de Poblete, 20 de junio de 1666, AHN, Inquisición, 1729.

73 «El capitán Juan Gómez de Payba, que lo es de una de las compañías de infantería española de las de dicho puerto». Auto de Francisco de Figueroa, Manila, 16 de diciembre de 1668, AHN, Inquisición, 1729. 
Corona de su paso por la alcaldía mayor de Pampanga, así como numerosos préstamos personales que su afición al juego no había ayudado a pagar. ${ }^{74}$ Por lo que, ya fuera por huir de la cohabitación con sus prestamistas, por no poder permitirse el nivel de vida de la capital filipina ${ }^{75} \mathrm{o}$ bien por preferir la tranquilidad del medio agrícola, el luso acabó trasladándose a la casa de campo que la familia de su mujer poseía en Santa Ana, ${ }^{76}$ la cual estaba situada, precisamente, en la ribera del río donde ocurrieron los hechos.

La noche del 12 de marzo de 1670, Gómez de Paiva se encontraba pernoctando en el poblado y parece que no participó directamente en el incidente. Si bien Antonio Vidal Serrano, uno de los marineros que acabó cautivo, le presentó como uno de los artífices de la respuesta violenta de los vecinos, el resto de los testimonios ni siquiera lo sitúan en el lugar de los hechos. ${ }^{77}$ La declaración de Vidal Serrano pudo estar condicionada por un desencuentro vivido entre ambos personajes, ya que, al recriminarle el marinero el mal trato que estaban sufriendo los «españoles» cautivos, Gómez de Paiva le propinó un fuerte golpe en la cara, mientras le profería sonoros insultos,$^{78}$ dejando entrever su postura en la disputa. Probablemente, el capitán portugués no se encontrara involucrado en el altercado y la declaración del mexicano derivase de la humillación vivida.

Así pues, debido a que no había participado en la refriega, al prestigio alcanzado durante su carrera pública y a que conocía personalmente tanto a los vecinos de Santa Ana como a algunos de los marineros del champán, ${ }^{79}$ Gómez de Paiva fue elegido mediador entre las partes por los monjes agustinos. De este modo, a las cinco de la tarde, el padre Barajas, Pablo de la Visitación y el capitán portugués se acercaron a parlamentar con los miembros del champán, mientras que los agraviados durante el asalto esperaban

74 «No tenían más que el socorro que se les dava de soldado y con esto, lo que ganavan, al juego». Testimonio de Isidro Salcedo, Manila, 17 de septiembre de 1693, AGI, Filipinas, 33, n. 2, d. 15.

75 «Que después quedó su muger que lo fue doña María Barandoa muy pobre, aviendo ostentado mucho fausto en esta ciudad». Testimonio de Juan de Miranda, Manila, 28 de agosto de 1693, AGI, Filipinas, 33, n. 2, d. 15.

76 «El jueves próximo pasado, doce del corriente, estando este testigo en la guerta de su tía doña María Barandoa, que está por tierra poca distancia de este pueblo». Testimonio de Juan Gómez de Paiva, 14 de marzo de 1670, AGI, Filipinas, 10, r. 1, n. 5.

77 «Y a su lado el capitán Juan Gómez de Payba así mismo con rodela y un espadín desnudo. Y un sargento reformado, su camarada, con espada desnuda, que este declarante no sabe su nombre». Testimonio de Antonio Vidal Serrano, Manila, 25 de marzo de 1670, AGI, Filipinas, 10, r. 1, n. 5.

78 «Y que en el camino porque este declarante dijo: así se tratan los españoles. A que dicho capitán Paiva le dijo alsando la mano: calle el cornudo ladrón y le dio una bofetada en el rostro». Idem.

79 «A los más marineros del champán, que conoce de vista, por haver asistido mucho tiempo en Cavite». Testimonio de Juan Gómez de Paiva, 14 de marzo de 1670, AGI, Filipinas, 10, r. 1, n. 5. 
para reclamar sus pertenencias. En primer lugar, se entregaron los cautivos. Al ser preguntados por el cabo Domingo García por el paradero de Bernardo Curiel y del indígena que faltaba en la tripulación, los representantes de Santa Ana se excusaron diciendo que desconocían su ubicación y que posiblemente se habían embarcado en otro de los navíos que iban rumbo a Lampón. ${ }^{80}$ La réplica era difícilmente creíble, de modo que los agustinos y Gómez de Paiva decidieron jugar las bazas disponibles y hacer alguna concesión para evitar futuras represalias: Determinaron no reclamar los alimentos robados, dejándolos a bordo del champán, y solicitar únicamente la devolución de los textiles robados al matrimonio de sangleyes. La pareja no tuvo mucha suerte pues, tras rebuscar en profundidad por todo el navío, solo dieron con una manta azul, permaneciendo el resto de enseres en manos de los asaltantes. ${ }^{81}$ Igual fortuna tuvo el africano Domingo de Ramos, quien, aunque pudo recuperar la guitarra de su amigo, no encontró ni rastro de su sombrero. ${ }^{82}$

Con todos los marineros finalmente a bordo del champán, la embarcación torció su viaje para dar fondo en Manila y no en Lampón, donde se la esperaba para seguir con el aderezo del galeón transpacífico ${ }^{83}$ San Diego. Una vez en la capital, diversos miembros de la tripulación, como Lucas de Pina, Agustín de Soto o José Sánchez, emprendieron acciones judiciales contra los agustinos y demás vecinos del poblado, a la vez que buscaban noticias de los desaparecidos. El percance acontecido en Santa Ana coincidió con un periodo convulso en el que las confrontaciones entre el estamento eclesiástico y los altos cargos de la Audiencia eran constantes. Uno de los principales artífices de este clima de tensión fue el propio gobernador, Manuel de León, quien, tras los sucesos acontecidos por su predecesor con la Inquisición, emprendió toda una serie de medidas encaminadas a limitar el poder de agustinos y dominicos en el archipiélago y a reforzar su poder

80 «Y faltó el dicho cavo Domingo García y Bernardo Curiel y un panday. Que dijo el padre no haverlos hallado y que pudiera ser que ubiesen ydo adelante a alcazar a los otros champanes que iban también a Lampón». Testimonio de Lucas de Pina, Manila, 13 de marzo de 1670, AGI, Filipinas, 10 , r. 1, n. 5 .

81 «Dicho padre subía a dicho champán a rreconozer su rropa, y que no halló más que una chinita de manta asul, y vio que el dicho padre entregó en dicho champán dos españoles y tres pampangos, a su parezer amarrados». Testimonio de Florentina de la Cruz, Santa Ana, 13 de marzo de 1670, AGI, Filipinas, 10, r. 1, n. 5.

82 «Los que avían saltado trayendo algunas gallinas muertas y arroz palay, y una guitarra, que traya un indio de dichos pandayes, la qual hizo volver este testigo a otro yndio de los de tierra que venía por ella». Testimonio de Lucas de Pina, Manila, 13 de marzo de 1670, AGI, Filipinas, 10, r. 1, n. 5.

83 Sobre el Galeón de Manila véase, entre otros, Bonialian, 2012; Martínez Shaw, 2019; SalesColin, 2000; Schurz, 1992; Yuste López, 2013. 
personal. ${ }^{84}$ No es de extrañar que el gobernador, al enterarse de lo acaecido en Santa Ana, instrumentalizara el suceso en beneficio propio. En una carta al Consejo de Indias donde narraba lo ocurrido en el poblado, Manuel de León intentaba demostrar cómo esto era un ejemplo más de los reiterados abusos cometidos por parte de ciertas órdenes en el medio agrícola filipino y de su actuación en contra de los intereses de la Monarquía. ${ }^{85}$ La misiva fue leída atentamente en Madrid y, aunque había pasado más de un año desde que acontecieron los hechos, se acordó el retorno de Francisco Barajas hasta la península ibérica, a pesar de las quejas de su orden, de su elevada edad y de lo penoso del trayecto ${ }^{86}$ Por su parte, la reacción de las autoridades filipinas fue bastante más dura. Pablo de la Visitación fue trasladado hasta el pueblo de Mauban, en los confines de la provincia de Camarines, una zona de escasa hispanización y alejada del esplendor de Manila. Antonio de Espíritu y el mestizo de español Ignacio Montes Doca fueron encarcelados por la muerte de los marineros y sus bienes fueron embargados por la Real Hacienda de las islas. Misma suerte corrió Juan Gómez de Paiva, a quien se le acusó de instigar la reacción violenta de los habitantes de Santa Ana. Este fue un golpe demasiado duro para el portugués, quien, con anterioridad, ya presentaba una situación económica sumamente delicada. Así, desesperado, accedió a aventurarse en una arriesgada empresa comercial orquestada

84 Durante su mandato, Manuel de León acotó el poder de los doctrineros, persiguiendo las ilegalidades cometidas por estos en las regiones más remotas del archipiélago. Interfirió en los capítulos provinciales de ciertas órdenes, llegando a encerrar y sitiar el consejo de la orden de San Agustín hasta que no se aceptaran los nombres propuestos por su persona. Colocó a un hombre de su confianza al mando de la Inquisición manileña, encarcelando a José de Patermina por su actuación contra el gobernador Diego Salcedo. Todo ello, mientras mantenía las peores relaciones posibles con el arzobispo de Manila Juan López, que le llevaron a una dura pugna por demostrar su superioridad tanto en el ámbito político como en el ceremonial. Consecuentemente, se granjeó una pésima reputación entre diversas facciones de la Iglesia en las islas, quienes mandaron numerosas cartas y memoriales a Madrid quejándose de su administración, a la vez que esparcían en las islas el rumor de que iba a ser remplazado en un término corto de tiempo. En cambio, su relación fue bastante buena con la Compañía de Jesús, a la que apoyó activamente en regiones como las Marianas o en la isla de Siau. «En que el gobernador es un tirano, ladrón, salvaje, y que esto no es lo peor, y que en la primera nao vendrá gobernador nuevo, que lo sabe de cierto un religioso grave que se lo dijo en secreto». Memorial escrito por un dominico anónimo, s/f, APSR, Historia Civil de Filipinas, manuscritos, t. 2.

85 «Los procedimientos de los religiosos, que asisten en los ministerios de las doctrinas de indios tan en contra del servicio de vuestra majestad y de su jurisdicción real [...] Capittanear los indios contra los españoles en lanze que se ocasionaron tres muertes [...] Con harto sentimiento, pues debiendo ser los primeros (como más benifiziados de la magnificencia de vuestra majestad) en fomentar su mayor servicio, lo son en ympedirle». Carta de Manuel de León, Manila, 10 de junio de 1670, AGI, Filipinas 10, r.1, n. 5.

86 «Fray Francisco de Barajas, de edad muy creçida, [...] y traer los religiosos de esta edad a España en distancia de cinco mil leguas con tanto peligro de vida». Carta de Fray Antonio de Somoza, 19 de septiembre de 1672, AGI, Filipinas, 86, n. 32. 
por el general Francisco García del Fresno, ${ }^{87}$ en la que se trasladó hasta Cantón, ciudad a la que ya había acudido en $1666 .{ }^{88}$ Pero durante estos años, la situación política del imperio chino había cambiado sensiblemente, y las leyes que prohibían la llegada hasta sus costas a mercaderes europeos se comenzaron a respetar más atentamente. El viaje acabó siendo un fracaso, desapareciendo Juan Gómez de Paiva y el resto de la tripulación sin dejar rastro alguno. ${ }^{89} \mathrm{~A}$ Manila llegaron únicamente rumores contradictorios sobre la muerte del capitán, mientras unos la situaban en la costa de China, otros lo hacían cerca del delta del Mekong.

\section{Santa Ana, un suceso local en el mundo interconectado del siglo XVII}

Aunque los hechos acontecidos durante el 12 de marzo de 1670 en Santa Ana se circunscribieron dentro de un ámbito local, gracias a este incidente podemos vislumbrar algunos de los vínculos que unían a este pequeño poblado con el resto del globo. Los bienes materiales detallados en los testimonios nos describen elementos que corresponden a realidades geográficas distantes entre sí, pero que conocieron en este pequeño enclave un punto de encuentro. Así pues, la guitarra que fue robada al pampango Diego de Catacotar es un objeto correspondiente a la tradición cultural europea, aunque no hay que descartar que se tratara de una variante o una adaptación local. El maíz que sembraba Domingo de Ramos es un cultivo originario de América y que consiguió extenderse por Filipinas, a pesar de no tratarse en ningún momento del cereal predominante en las islas ni de estar fuertemente enraizado en la dieta de sus habitantes. Es posible que se tratara de un cultivo

87 Este personaje aparece recurrentemente ligado tanto al comercio transpacífico como al comercio con otros países asiáticos. Así pues, ostentó durante los años 1662-1663 el cargo de capitán general del Galeón de Manila San José y durante la década de 1670 realizó negocios junto a mercaderes armenios en la costa de la India. Registro notarial, Manila, 29 de octubre de 1674, National Archives of Philippines-Biblioteca Tomás Navarro Tomás, Madrid, Colección de documentos españoles del Archivo Nacional de Filipinas, 3534. Herrera Reviriego, 2013.

88 «Y le despachó al reyno de Cantón en China a cargo de un cappitán portugués, Juan Gómez de Payba, metiendo en él veinte y quatro marineros, ocho artilleros españoles, infantería neçessarios todos, y ocho piesas de artillería de bronze de la que tienen estas yslas en su defenza. [En]biando en el suyos y de particulares más de 100.000 pesos para emplear en Cantón». Carta del arzobispo Miguel de Poblete, 20 de junio de 1666, AHN, Inquisición, 1729, exp. 11.

89 «Juan Gómez de Paiba, el qual llegó a estar muy pobre, que ni aún tenía para enter[r]arse, por cuya causa, compadeciéndose de su pobresa el general Francisco García del Fresno, le avió, ymbiándole por capitán de un navío al reyno de Cantón. Donde fue a muchos años, y hasta agora no se a tenido noticias de dicho capitán ni del navío en que fue». Testimonio de Tomás Ibáñez, Manila, 6 de septiembre de 1693, AGI, Filipinas, 33, n. 2, d. 15. 
destinado a su venta en la ciudad de Manila, puesto que muchos de sus habitantes de origen americano o europeo se resistían a abandonar las tradiciones de sus respectivos territorios. Los textiles robados en casa de Florentina de la Cruz y Jacinto Suco tenían una procedencia diversa, como las «sayas» y «chininas» que solían llegar hasta el archipiélago en grandes cantidades desde las costas de China o Taiwán, o las «cambayas» procedentes de Siam, Insulindia o India. Estos tejidos eran en su mayoría manufacturas de algodón, ${ }^{90}$ y constituían el grueso del contenido de las bodegas de los galeones de Manila desde la caída de la dinastía Ming, debido en parte a la escasez de las exportaciones de seda procedentes de Fujian. ${ }^{11}$ Por su parte, las catanas que portaban tanto Jacinto del Rosario como otros miembros de la principalía indígena nos muestran los sólidos vínculos que habían mantenido durante años Filipinas y Japón, y que, a pesar del cierre de fronteras del país nipón a los hispánicos, habían sobrevivido de la mano de intermediarios chinos, neerlandeses y daneses. ${ }^{92}$ Así pues, podemos apreciar cómo diversos flujos culturales, comerciales y económicos se unían en Santa Ana, insertando a este pequeño poblado filipino dentro de un contexto comercial asiático, pero con una influencia cultural y administrativa europea y americana.

Además, la presencia de múltiples y variados materiales asiáticos en el poblado esboza la existencia de un mercado interior filipino, en el que los productos procedentes de fuera de los límites del archipiélago pudieron tener una especial relevancia. Se rompe así con la tradicional visión de Filipinas como una simple escala en el tránsito de mercancías entre China y América, pues muestra cómo este archipiélago era capaz de absorber parte de los productos asiáticos llegados hasta Cavite y que su posesión no estaba limitada a unos pocos grandes mercaderes vinculados a Acapulco. Del mismo modo, la figura de Francisco Gómez de Paiva pone en entredicho — una vez más_ la visión de los vecinos de Manila como meros reexportadores de mercancías chinas, que vivían acomodados y ociosos a la espera de los vaivenes del viaje anual del galeón. ${ }^{93}$ El devenir de este mercader evidencia un gran dinamismo, aunque escasa fortuna, permaneciendo activo en las redes comerciales del sudeste asiático al mismo tiempo que ascendía en el cursus honorum de la Monarquía e interactuaba con el trato interior del archipiélago.

90 Registro de navíos efectuados por el fiscal de la Audiencia Diego Antonio de Viga, AGI, Filipinas, 64, n. 1.

91 Fang, 2012.

92 Laarhoven y Pino Wittermans, 1985.

93 «Los españoles no trabajaban, no necesitaban hacerlo. Como consecuencia de ello, jamás explotaron ni uno solo de los recursos de las islas». Kamen, 2003, 253. 
La diversidad de los orígenes de los vecinos de Santa Ana y de los marineros del champán también nos muestra la exposición de este poblado a los flujos e interconexiones internacionales. ¿Cómo de otro modo podríamos encontrar en un enclave tan pequeño reunidos a portugueses, chinos, africanos, colombianos, mexicanos, castellanos, indígenas filipinos, venezolanos y diferentes mestizos de chino e indígena, «español» e indígena y «español» y africano? Esta diversidad étnica nos muestra un escenario complejo en los que los hechos narrados solo son capaces de vislumbrar sus capas más superficiales. A pesar de las diferencias culturales y étnicas, en Santa Ana se había generado una identidad común de vecindad y unos lazos mutuos que, tras el detonante de un desafío externo, había permitido la unión de la comunidad. Muestra de ello se nos da en la reacción de Gómez de Paiva al ser increpado por Antonio Vidal Serrano, aludiendo al origen étnico común diciendo: «así se tratan los españoles», ${ }^{44}$ pesando más en la reacción del capitán los lazos de vecindad que la pertenencia a un grupo étnico común.

Esta diversidad de orígenes presente en Santa $\mathrm{Ana}^{95}$ también rompe con la clásica división de poblaciones en territorio filipino, según la cual, los europeos y americanos que no sirvieran en el ejército o en el mar pasaban las noches en el barrio de Intramuros de la ciudad de Manila, los chinos solo podían vivir en el Parián de los Sangleyes o Alcaicería y los africanos en una isla junto al pueblo de Santa Cruz. Esta división, después de comprobar la variedad étnica de este poblado, se antoja cuanto menos artificial y sumamente encorsetada. Santa Ana no habría sido un caso especial, tan solo nos muestra un ejemplo de esta diversidad. Son diversas las fuentes que nos hablan de cómo muchos de los vecinos de Manila se trasladaban en el periodo estival hasta casas de campo fuera del perímetro amurallado de la ciudad y, preferentemente, junto al río Pasig. Además, con el trascurso del siglo, algunos manileños abrieron vías de negocio alternativas, aunque

94 Esto también nos muestra lo amplio que era el uso de la palabra «español» en Filipinas, puesto que a pesar de que Gómez de Paiva había nacido en territorio luso y de que Vidal Serrano era mexicano, ambos se consideraban y se les consideraba «españoles». Es más, Vidal y Serrano posiblemente era un indígena americano o tenía sangre americana corriendo por sus venas, puesto que Jacinto del Rosario pudo identificar que procedía de Nueva España solo con verle. «Tenían junto a si amarrados siete hombres, los cinco naturales y los dos que le parecieron de la Nueva España». Testimonio de Jacinto del Rosario, Santa Ana, 14 de marzo de 1670, AGI, Filipinas, 10, r. 1, n. 5.

95 A pesar de la variedad de nacionalidades presentes en Santa Ana, no estaban representadas en este pequeño enclave todas las presentes en las islas en estos momentos. Así, por ejemplo, no encontramos japoneses ni mardicas como en otros pueblos de Tondo como Bagumbayan. «Este testigo oyó a Lorenzo Machado, sargento mayor de los mardicas que asiste en Bagumbaya, extramuros de esta ciudad». Testimonio de Sebastián Rayo Doria, Manila, 4 de septiembre de 1668, AHN, Inquisición, 1729. 
complementarias, al comercio transpacífico en las provincias cercanas, como las granjas de ganado vacuno, ${ }^{96}$ trasladándose ellos mismos o personas de su confianza hasta las mismas. Por su parte, en 1670, la difusión de los sangleyes por parte de las tierras bajas de Luzón era ya una realidad, ${ }^{97}$ y las autoridades filipinas no tuvieron más remedio que reconocer su dispersión y legalizar su asentamiento fuera del Parián. ${ }^{98}$

También hay que tener en cuenta que la chispa que encendió el asalto sobre Santa Ana pudo estar vinculada con la crisis económica que vivía en estos momentos la gobernación de Filipinas. La cual estuvo íntimamente ligada con las perturbaciones internacionales, como el colapso de la dinastía Ming, los problemas surgidos con los enclaves portugueses de Asia tras la ruptura de los Braganza o el aislamiento japonés, que habían provocado un descenso en el número, variedad y valor de las mercancías llegadas hasta Manila. Esta redefinición del comercio filipino, unida al aumento del gasto público en partidas defensivas, al descenso en los situados procedentes de México y a la inestabilidad política, tuvo graves consecuencias para la economía de la gobernación, provocando un reajuste en las partidas presupuestarias de 1670 que, en último término, acabaron desembocando en la falta de víveres del champán y en el asalto de sus marineros al poblado. En definitiva, a pesar de la tranquilidad y el aparente aislamiento de Santa Ana, se puede apreciar cómo este enclave estuvo estrechamente vinculado a las dinámicas y grandes movimientos de la historia global. Se nos muestra así un claro ejemplo de que la conocida como «primera globalización» no se quedó en unas pocas ciudades de relevancia, sino que tuvo un amplio radio de influencia e, incluso, afectó a pequeños poblados de regiones consideradas como «periféricas» por parte de la historiografía durante años.

Por su parte, Santa Ana también nos revela algunos de los factores que caracterizaron los poblados y barangayes filipinos del siglo XVII. Así pues, podemos contemplar una economía centrada en el cultivo de arroz, como en muchas otras regiones del archipiélago y sureste asiático, aunque

96 «A doña Clara de Molina y Figueroa, viuda, vezina de esta ciudad, treinta pesos de oro común, que por decreto del govierno, se le pagaron a quenta de sietecientos y sesenta y quatro pesos y quatro tomines, que se le libraron por el valor de dozientas y veinte y siete rezes bacunas, que desde diez de noviembre del año pasado de mill y seiscientos y sesenta hasta diez de febrero de mill y seiscientos y sesenta y cinco dio de su estançia». Informe de los géneros y manufacturas compradas para los Reales Almacenes, Manila, 1665, AGI, Contaduría, 1237.

97 La presencia de estos sangleyes en Tondo perduró y se asentó durante las décadas siguientes, alcanzando las 4.000 personas en 1741. Fenómeno que también ocurría con los mestizos de sangley, pudiendo encontrar 30.420 de ellos en 1753 en el conjunto del archipiélago. Manchado López, 1999.

98 Carta de Manuel de León, Manila, 15 de junio de 1671, AGI, Filipinas, 10, r. 1, n. 7. 
con la presencia de otros productos agrícolas como el maíz o los rábanos, procedentes de otros enclaves, en una clara adaptación a los gustos y usos de la cada vez más diversa población de Luzón. También se puede apreciar la importancia de la ganadería aviar en este barangay, así como el papel destacado de los carabaos en el medio agrario filipino.

Por otro lado, gracias a las figuras de los hermanos Antonio de Espíritu y José de la Cruz, podemos comprobar los fuertes vínculos que mantenían los principales indígenas tanto con las autoridades de la gobernación como con los miembros de su comunidad. De modo que, a pesar de gozar de una serie de privilegios, obtenidos gracias a su colaboración con las autoridades hispánicas, no dudaron en defender a sus convecinos, participando activamente en las refriegas, aunque esto pudiera reportarles futuros problemas con la justicia, el alcalde mayor de Tondo o las autoridades manileñas. Ambos hermanos son una muestra clara de la adopción por parte de las élites indígenas de ciertos elementos de la cultura hispánica, siendo los únicos de los naturales del barangay interrogados que podían hablar y entender sin esfuerzos la lengua castellana. Al mismo tiempo, esto incide en lo superficial que fue la aculturación del territorio filipino, pues, tras casi una centuria de presencia hispánica en Luzón, una gran mayoría de los pobladores de los territorios agrícolas en torno a Manila continuaban hablando en tagalo y presentando severas dificultades para entender y expresarse en castellano. No obstante, los sucesos acontecidos en Santa Ana nos muestran cómo la religión católica sí consiguió adentrarse dentro de esta región, modificando las mentalidades y costumbres de sus habitantes. Destaca la elevada importancia que obtuvieron los eclesiásticos dentro de estas comunidades, convirtiéndose en un foco irradiador de autoridad y desarrollando competencias que, en muchos casos, superaban el ámbito religioso y que les acabaron enfrentando con unas autoridades manileñas que, durante la segunda mitad del siglo XVII, fueron prestando cada vez mayor atención hacia las provincias filipinas.

Como podemos apreciar por el testimonio de los habitantes de Santa Ana, este mundo agrícola filipino contaba con unos tiempos, formas y circunstancias propias vinculadas - aunque relativamente alejadas- de los problemas económicos y las carestías que estaba viviendo la capital filipina en estos momentos. El conflicto vivido entre los tripulantes del champán y los vecinos del barangay puede llegar a interpretarse como el choque de dos «mundos», uno agrícola y otro urbano. Los cuales, aunque estaban claramente interconectados entre sí y compartían tanto una cronología como 
un espacio conjunto, presentaban dinámicas, características y tiempos propios. Así pues, los marineros se encontraban fuertemente insertos en las necesidades y tendencias manileñas, intrínsecamente unidas al devenir de la gobernación de Filipinas, a la administración hispánica y a la llegada de mineral argénteo desde Nueva España; mientras que los habitantes de Santa Ana contaban con sus propias dinámicas, más enfocadas a los tiempos de cosecha, siembra y recolección que a los viajes anuales de imponentes navíos transpacíficos y a las necesidades que estos pudieran presentar. Los hechos del 12 de marzo de 1670 pueden llegar a ser interpretados como un encuentro entre dos realidades con necesidades diferenciadas que, al encontrarse en un mismo espacio, dieron lugar a un conflicto violento. Aunque esto no significa que no existiera vinculación entre el mundo urbano y el mundo agrícola filipino, pues existían claros puentes que los unían como el papel de los cabezas de barangay, la subordinación a la administración hispánica, el pago de impuestos o algunas labores de los religiosos presentes en el núcleo de población. Como hemos podido apreciar, Santa Ana no era una pieza disociada del resto de los territorios filipinos, hispánicos, asiáticos y del resto del orbe, sino que estuvo interconectada con ellos, presentando unos vínculos de mayor o menor intensidad con otras regiones que modificaron sus formas de vida y la conectaron con el mundo globalizado de la segunda mitad del siglo XVII.

Recibido, 2 de enero de 2021 Segunda versión, 23 de mayo de 2021 Aceptado, 7 de junio de 2021

\section{Referencias bibliográficas}

Alfonso Mola, Marina y Martínez Shaw, Carlos, «The Philippine Island: A Vital Crossroads During the First Globalization Period», Culture \& Digital Journal, 3:1, Madrid, 2014, 1-16.

Alonso Álvarez, Luis, «Los señores del barangay. La principalía indígena en las islas Filipinas, 1565-1789: Viejas evidencias y nuevas hipótesis», en Menegus Bornemann, Margarita y Aguirre Salvador, Rodolfo (coords.), El cacicazgo en Nueva España y Filipinas, México, Plaza y Valdés, 2005, 261-280.

Alva Rodríguez, Inmaculada, «Manila y sus arrabales: Un lugar de encuentro entre culturas (siglo XVI-XVIII)», en Manchado López, Marta María y Luque Talaván, Miguel (coords.), Un mar de islas, un mar de gentes. Población y diversidad en las islas Filipinas, Córdoba, Universidad de Córdoba, 2014, 207-222. 
Andrade, Tonio, «A Chinese Farmer, Two African Boys, and a Warlord: Toward a Global Microhistory», Journal of World History, 21:4, Honolulu, 2011, 573-592.

Baudot Monroy, María, «Lampón, puerto alternativo a Cavite para el Galeón de Manila», Vegueta. Anuario de la Facultad de Geografía e Historia, 20, Las Palmas de Gran Canaria, 2020, 21-48.

Bertrand, Romain, «Where the Devil Stands: A Microhistorical Reading of Empires as Multiple Moral Worlds (Manila-Mexico, 1577-1580)», en Ghobrial, John-Paul (ed.), Global History and Microhistory, Oxford/New York, Oxford University Press, 2019, 83-109.

Bonialian, Mariano, El Pacífico hispanoamericano. Política y comercio asiático en el imperio español, 1680-1784. La centralidad de lo marginal, México, El Colegio de México, 2012.

Bonialian, Mariano, «Relaciones económicas entre China y América Latina. Una historia de globalización», Historia Mexicana, 70:3, Ciudad de México, 2021, 1231-1273.

Brook, Timothy, Veermeer's Hat: The Seventeenth Century and the Dawn of the Global World, Nueva York, Profile Books, 2008.

Camañaque Jiménez, Francisco, Recuerdos de Filipinas. Cosas, casos y usos de aquellas islas, Madrid, Librería de Anillo y Rodríguez, 1877.

Corpuz, Onofre D., The Roots of Filipino Nation, Quezon City, The University of Philippines Press, 2005.

De Vries, Jan, «Playing with the Scales: The Global and the Micro, the Macro and the Nano», en Ghobrial, John-Paul (ed.), Global History and Microhistory, Oxford/New York, Oxford University Press, 2019, 23-36.

Fang, Chenchen, 華人與呂宋貿易 (1657-1687): 史料分析與譯註, Hsinchu, National Tsing Hua University Press, 2012.

Fernández Palacios, José María, «El papel activo de los indígenas en la conquista y defensa de las islas Filipinas: las compañías pampangas en el siglo XVII», en Manchado López, Marta María y Luque Talaván, Miguel (coords.), Un mar de islas, un mar de gentes. Población y diversidad en las islas Filipinas, Córdoba, Universidad de Córdoba, 2014, 101-124.

Fernández Palacios, José María, «En todas las ocasiones que se ofrecen sirven a vuestra majestad: señores y principales pampangos en el real servicio de las Filipinas del siglo XVII», Boletín de la Real Academia de la Historia, 216:2, Madrid, 2019, 189-245.

Flynn, Dennis y Giraldez, Arturo, «Born with a Silver Spoon: The Origins of World Trade in 1571», Journal of World History, 6, Honolulu, 1995, 201-221.

Ghobrial, John-Paul, «The Secret Live of Elias of Babylon and the Uses of Global Microhistory», Past \& Present, 222:1, Oxford, 2014, 51-93.

Gunn, Geoffrey, First Globalization. The Eurasian Exchange, 1500-1800, Lanham, Rowman and Litterfierld, 2003. 
Herrera Reviriego, José Miguel, «Motín a bordo: conflicto y lucha de jurisdicciones en el galeón San José (1662-1663)», en Bernabéu Albert, Salvador (coord.), La nao de China, 1565-1815. Navegación, comercio e intercambios culturales, Sevilla, Universidad de Sevilla, 2013, 65-91.

Herrera Reviriego, José Miguel, «Flujos comerciales interconectados: el mercado asiático y el americano durante la segunda mitad del siglo XVII», Historia Mexicana, 66:2, México, 2016, 495-553.

Huerta, Félix de, Estado Geográfico, topográfico, estadístico, histórico-religioso de la santa apostólica provincia de San Gregorio Magno, Manila, Imprenta de los Amigos del País, 1855.

Kamen, Henry, La forja de España como potencia mundial, Madrid, Aguilar, 2003.

Laarhoven, Ruurdje y Pino Wittermans, Elizabeth, «From Blockade to Trade: Early Dutch Relations with Manila», Philippine Studies, 33:4, Manila, 1985, 485-504.

Larkin, John A., The Pampangans. Colonial Society in a Philippine Province, Quezon City, New Day Publishers, 1993.

Levi, Giovanni, «Microhistoria e Historia Global», Historia crítica, 69, Bogotá, 2018, 21-35.

Lopes, Maria Antónia, «Manuel Soares de Oliveira, assessor e auditor do governador das Filipinas e benfeitor da Misericórdia de Coimbra (1598-1675)», en Fernández Chaves, Manuel Francisco y Pérez García, Rafael M. (coords.), Movilidad, interacciones y espacios de oportunidad entre Castilla y Portugal en la Edad Moderna, Sevilla, Universidad de Sevilla, 2019, 275-295.

Manchado López, Marta María, «El proyecto de convento para mestizas de Santa Rosa de Lima, en Filipinas», Anuarios de Estudios Americanos, 51:2, Sevilla 1999, 485-512.

Martínez Shaw, Carlos, «El Galeón de Manila: 250 años de intercambios», Estudis: Revista de Historia Moderna, 45, Valencia, 2019, 9-34.

Martínez Torres, José Antonio, «"There is but one world”: Globalisation and connections in the overseas territories of the Spanish Habsburgs (1581-1640)», Culture \& History Digital Journal, 3:1, Madrid, 2014, 1-15.

McNeill, John Robert y McNeill, William Hardy, Las redes humanas: una historia global del mundo, Barcelona, Crítica, 2004.

O'Brien, Patrick, «Historiographical Traditions and Modern Imperatives for the Restoration of Global History», Journal of Global History, 1, Cambridge, 2006, 3-39.

Phelan, John Leddy, The Hispanization of the Philippines. Spanish Aims and Filipino Responses. 1565-1700, Londres, The University of Wisconsin Press, 1967.

Polanco, Fernando, «Resistencia y rebelión indígena en Filipinas durante los primeros cien años de soberanía española», en Cabrero Fernández, Leoncio (ed.), España y el Pacífico. Legazpi, Madrid, Sociedad Estatal de Conmemoraciones Culturales, 2004, 209-248. 
Pons, Anaclet y Serna, Justo, Cómo se escribe microhistoria: ensayo sobre Carlo Ginzburg, Valencia, Universitat de València, 2000.

Prieto Lucena, Ana María, El contacto hispano-indígena en Filipinas, Córdoba, Universidad de Córdoba, 1993.

Renato, Constantino, A History of the Philippines: From the Spanish Colonization to the Second World War, Nueva York/Londres, Monthly Review Press, 1976.

Ruiz Ibáñez, José Javier, «De lo local a lo global», en Martínez Alcalde, María y Ruiz Ibáñez, José Javier (eds.), Felipe II y Almazarrón: la construcción local de un imperio global. Vivir, defender y sentir la frontera, Murcia, Ediciones de la Universidad de Murcia/Red Columnaria, 2014, 13-18.

Sales-Colin, Ostwald, El movimiento portuario de Acapulco: el protagonismo de Nueva España en la relación con Filipinas, 1587-1648, México, Plaza y Valdés, 2000.

Sánchez Gómez, Luis, Las principalías indígenas y la administración española en Filipinas, Madrid, Universidad Complutense de Madrid, 1989.

Sánchez Pons, Jean-Noël, «Tardíos amores insulindios: Manila y el sultanato de Macasar en el siglo XVI», Vegueta. Anuario de la Facultad de Geografía e Historia, 20, Las Palmas de Gran Canaria, 2020, 295-325.

Schreurs, Peter, «The Governor-General, the Inquisition and the Dutch Connection (Manila, 1664-1669)», Hispania Sacra, 41, Madrid, 1989, 131-145.

Schurz, William Lytle, El galeón de Manila, Madrid, Instituto de Cooperación Iberoamericana, 1992.

Subrahmanyam, Sanjay, «Connected Histories: Notes Towards a Reconfiguration of Early Modern Eurasia», Modern Asian Studies, 31:3, Cambridge, 1997, 735-762.

Subrahmanyam, Sanjay, «Par-delà l'incommensurabilité: pour une histoire connecteé des empires aux temps modernes», Revue d'histoire moderne et contemporaine, 54:4bis, París, 2007, 34-53.

Subrahmanyam, Sanjay, Aux origines de l'histoire globale, París, Collège de France, 2014.

Tremml-Werner, Birgit, «Marginal Players and Intra-network Connections: New Perspectives on the Manila Trade, c.1640-1780», Journal of Social Sciences and Philosophy, 29:4, Taiwan, 2017, 599-626.

Trivellato, Francesca, «Is There a Future for Italian Microhistory in the Age of Global History?», Californian Italian Studies, 2:1, Oakland, 2011. Disponible en: https://doi.org/10.5070/C321009025 [Consultado: 20/05/2021].

Yuste López, Carmen, «Nueva España, el cabo americano del Galeón de Manila», en Brasó Broggi, Carles (coord.), Los origenes de la globalización: el galeón de Manila, Shangai, Biblioteca Miguel de Cervantes de Shanghai, 2013, 105-126. 